\title{
1 Gobies (Perciformes: Gobiidae) in Bolinao, northwestern Philippines
}

\section{Running head: Gobies of Bolinao}

3 Klaus M. Stiefel ${ }^{1,2, *}$, Dana P. Manogan ${ }^{1}$, and Patrick C. Cabaitan ${ }^{1}$

$4{ }^{1}$ The Marine Science Institute, University of the Philippines, Diliman, Quezon City, Philippines

$5 \quad$ Neurolinx Research Institute, La Jolla, CA, USA

$7 \quad{ }^{*}$ Corresponding author: Klaus M. Stiefel

8 klaus@,neurolinx.org

9 University of the Philippines Diliman, Marine Science Institute

10 P. Velasquez St., Diliman, Quezon City, Philippines 1101

11 phone: +6329223959

12

13 Keywords: Bolinao, Coral Reef, Fish, Gobiidae, Philippines

14

15

16 


\section{Abstract:}

18 We conducted a visual and photographic survey of the gobiidae in the Bolinao area of the

19 Philipines, located on the western tip of the Lingayen gulf, on the west coast of Luzon island. We

20 identified a total of 40 species, of which 18 are shrimp-associated. One species found (Myersina

21 lachneri) constitutes a range expansion into the Philippines. This number of species is in the

22 expected range compared to other studies of marine goby faunae in the coral triangle, despite the

23 significant anthropogenic pressures onto the marine ecosystem in the surveyed area. 
30 Gobies (Perciformes: Gobiidae) are the largest family of marine fishes, with over 1800 known

31 species (1834 listed on Fishbase, Froese \& Pauly, 2010). In tropical coastal ecosystems, gobies

32 constitute a significant fraction of all fish species. Many species of gobies are cryptic, living as

33 epibionts on corals and sponges, or highly camouflaged in the sand. About 120 species of marine

34 gobies also live in a symbiotic relationship with alpheid shrimp, with which they share a burrow

35 excavated by the shrimp. In mangrove areas, mudskippers of the genus Pteriophtalmus are

36 amphibious and venture out onto the mud between the mangrove roots. Most species of gobies

37 are small, with Schindleria brevipinis possibly the smallest known vertebrate (7 mm adult length,

38 Watson \& Walker, 2004). Generally, knowledge of the gobiid fauna provides a valuable window

39 into the fish diversity of a location.

40

41

\section{MATERIALS \& METHODS}

43

44 We used visual and photographic identification by two or three observers during SCUBA dives

45 to survey an area of about $75 \mathrm{~km}^{2}$ around Santiago island east of Bolinao on the western edge of

46 the Lingayen gulf (Fig. 1; $16^{\circ} 24^{\prime} 32^{\prime}$ ' North, $119^{\circ} 56^{\prime} 13$ ”' East), northwestern Philippines.

47

48 The sampling sites were between 1 and 35 meters deep, with the majority of species found

49 shallower than 18 meters. Habitats included coral reefs, sandy areas adjacent to reefs, sandy/silty

50 areas not in proximity to coral reefs, as well as seagrass areas. An unusual sampling site is the 
51 giant clam ocean hatchery of the University of the Philippines Marine Science Institute, which is

52 home to several thousand giant clams (Tridacna spp.). These clams provide 3-dimensional

53 structure similar to a coral reef. We excluded esturine, brackish water and freshwater habitats.

54

55 The anthropogenic disturbances of the marine environment in the western Lingayen gulf are

56 significant, with fish farms introducing a significant amount of nutrients, and strong artisanal and

57 large-scale fishing operations depleting fish stocks (McManus, 1992; Campos et al., 1994). The

58 drop in water quality caused by the fish farming on the west side of Santiago Island has led to

59 coral reef degradation and in some spots to a conversion of former reefs to silty areas devoid of

60 corals (Cabaitan et al., 2016).

61

62

\section{RESULTS}

63

64 We found a total of 40 species of gobiidae, of which 18 were shrimp-associated, 7 were coral

65 epibionts at least part of the time, 14 were sand-living, 1 found in rubble and 1 in rock crevices

66 (Table 1, Fig. 2).

67

68 We found individuals of all but two species (Gobiodon sp., Gobiodon ceramenis) multiple times,

69 indicating that while our sampling of the goby species in the area might not be complete, we had

70 found all but the most rare species.

71

72 Gobiodon sp., a yellow fish with orange facial markings, is likely the undescribed species listed

73 in Allen \& Erdmann (2012). Myersina lachneri (Hoese \& Lubbock, 1982) is a range expansion 
74 for the Philippines, having previously only been reported from Papua New Guinea and Indonesia

75 (Allen \& Adrim, 2003).

76

77 Photographs of 31 of the 41 described species are available here:

78 https://www.flickr.com/photos/pacificklaus/sets/72157685611197132

79 Video footage of several species featured in the photographs, and two more are available here:

80 https://www.youtube.com/watch?v=Q4KMPjV0qSg

81

82

83

\section{DISCUSSION}

84

85 Our survey found 40 species of gobies in an area of about $75 \mathrm{~km}^{2}$. This is close to an expected

86 number of species compared to other surveys of gobbiidae in the Indo-Pacific (see Fig. 3 for a

87 species-area plot as the basis for this prediction). Surveying an area of a comparable size (40

$88 \mathrm{~km}^{2}$ ), Depczynski \& Bellwood (2005) found 30 species around Lizard Island in the GBR.

89

90 The goby fauna in the western Lingayen near Bolinao gulf is likely determined by the physical

91 conditions as well as by anthropogenic disturbance. The area lacks deep walls which are habitats

92 for hovering gobies (such as Trimma tevegae), which are hence absent from the area.

93 Additionally, the eastern side of Santiago island is swept by powerful currents, known to limit

94 the occurrence of small marine fishes (Depczynski \& Bellwood, 2005). The low number of

95 gobiid epibionts is most likely a consequence of the limited coral cover and diversity. This might

96 partially be a consequence of the severe anthropogenic stresses to marine habitats in the region. 
97 Nevertheless, a gobiid fauna of 40 species, close to the expected value, indicates that small, often

98 cryptic, fishes low in the food web could be less likely affected by anthropogenic disturbances

99 than larger species.

100

101

\section{ACKNOWLEDGMENTS}

102

103 We would like to thank our colleagues at the University of the Philippines, Diliman, Marine

104 Science Institute, especially Renato Adolfo for help in sampling, Dr. Cecilia Conaco and

105 Timothy Quimpo for helpful discussion. We also thank Andreas Völkers and Dr. Brett Tibbatts

106 for help with fish identification, and Dr. Rene Abesamis for discussion and pointers to the

107 literature.

\section{REFERENCES}

ABAN SM, GARCIA AC, MERCADO RA, FERRER MM. 2017 Resource assessment of Tambac Bay in Western Pangasinan, Philippines. Pangasinan State University Journal of Natural and Allied Sciences, 1: 23-31.

114 ALLEN GR \& ADRIM M. 2003. Coral reef fishes of Indonesia. Zoological Studies, 42(1):1-72.

115 ALLEN GR \& ERDMANN MV. 2009. Reef fishes of the bird's head peninsula, West Papua, Indonesia. Check List, the journal of biodiversity data, 5(3): 587-628.

ALLEN GR \& ERDMANN MV. 2012. Reef fishes of the East Indies. Conservation International Foundation, $1292 \mathrm{pp}$.

CABAITAN PC, GOMEZ ED, YAP HT 2016. The spaghetti sponge Callyspongia samarensis (Wilson, 1925) provides temporary habitat for reef fish recruits. Marine Biodiversity, 46: 541-542.

CAMPOS WL, DEL NORTE-CAMPOS AGC, MCMANUS JW. 1994. Yield estimates, catch, effort and fishery potential of the reef flat in Cape Bolinao, Philippines. Journal of Applied Ichthyology, 10: 82-95.

DEPCZYNSKI M \& BELLWOOD DR. 2005. Wave energy and spatial variability in community structure of small cryptic coral reef fishes. Marine Ecology Progress Series, 303: 283293. 
128 FROESE R \& PAULY D. 2017. FishBase. World Wide Web electronic publication.

$129 \quad$ Www.fishbase.org (Accessed 20 June 2018).

130

LARSON HK, JAAFAR Z, LIM KPK. 2016. An updated checklist of the gobioid fishes of

131

132 Singapore. The Raffles Bulletin of Zoology, 34: 744-757.

MCMANUS JW, NAÑOLA CL JR., REYES RB JR., KESNER KN. 1992. Resource ecology of the Bolinao coral reef system. ICLARM Stud. Rev., 22, 117 pp.

STIEFEL KM, MERRIFIELD A, REED M, JOYCE DB 2014. A comparison of the gobiid fauna doi: https://doi.org/10.1101/006049.

WATSON W \& WALKER HJ. 2004. The world's smallest vertebrate, Schindleria brevipinguis, a new paedomorphic species in the family Schindleriidae (Perciformes: Gobioidei). 
141 Table 1. All gobiid species recorded in the vicinity of Bolinao, northwestern Philippines.

142

\begin{tabular}{|c|c|c|}
\hline \multicolumn{2}{|c|}{ Shrimp-associated gobies } & \multirow[t]{2}{*}{ Niche } \\
\hline Genus & Species & \\
\hline Amblyeleotris & steinitzii & shrimp \\
\hline Amblyeleotris & fortanesii & shrimp \\
\hline Amblyeleotris & periopthalama & shrimp \\
\hline Amblyeleotris & wheeleri & shrimp \\
\hline Amblyeleotris & guttata & shrimp \\
\hline Amblyeleotris & gymnocephala & shrimp \\
\hline Cryptocentrus & ceruleomaculatus & shrimp \\
\hline Cryptocentrus & leptocephalus & shrimp \\
\hline Cryptocentrus & sericus & shrimp \\
\hline Cryptocentrus & strigilliceps & shrimp \\
\hline Cryptocentrus & cyanotaenia & shrimp \\
\hline Mahidolia & mystacina & shrimp \\
\hline Ctenogobiops & crocineus & shrimp \\
\hline Vanderhorstia & dorsomaculata & shrimp \\
\hline Vanderhorstia & macropteryx & shrimp \\
\hline Vanderhorstia & ambanoro & shrimp \\
\hline Vanderhorstia & ornatissima & shrimp \\
\hline Tomiyamichthys & oni & shrimp \\
\hline Myersina & lachneri & shrimp \\
\hline \multicolumn{3}{|c|}{ Non-shrimp associated gobies } \\
\hline Pleurosycia & michelii & coral epibiota \\
\hline Bryaninops & yongei & coral epibiota \\
\hline Gobiodon & $\mathrm{sp}$ & coral epibiota \\
\hline Gobiodon & ceramenis & coral epibiota \\
\hline Eviota & pellucida & coral epibiota/rock \\
\hline Eviota & prasites & coral epibiota/rock \\
\hline Eviota & stigillata & coral epibiota/rock \\
\hline Trimma & caesuria & rock crevice \\
\hline Asterropteryx & striatus & rubble \\
\hline Acentrogobius & nebulosus & sand \\
\hline Amblygobius & phalaena & sand \\
\hline Amblygobius & nocturnus & sand \\
\hline Amblygobius & buanensis & sand \\
\hline Istigobius & decoratus & sand \\
\hline Coryphopterus & aureus & sand \\
\hline Valencienna & puellaris & sand \\
\hline Valencienna & sexguttata & sand \\
\hline
\end{tabular}




\begin{tabular}{|ll|l|} 
Oplompus & oplompus & sand \\
Oplompus & caninoides & sand \\
Heteroplopomus & barbatus & sand \\
Exyrias & belissimus & sand \\
\hline Exyrias & puntang & sand/seagrass \\
\hline
\end{tabular}

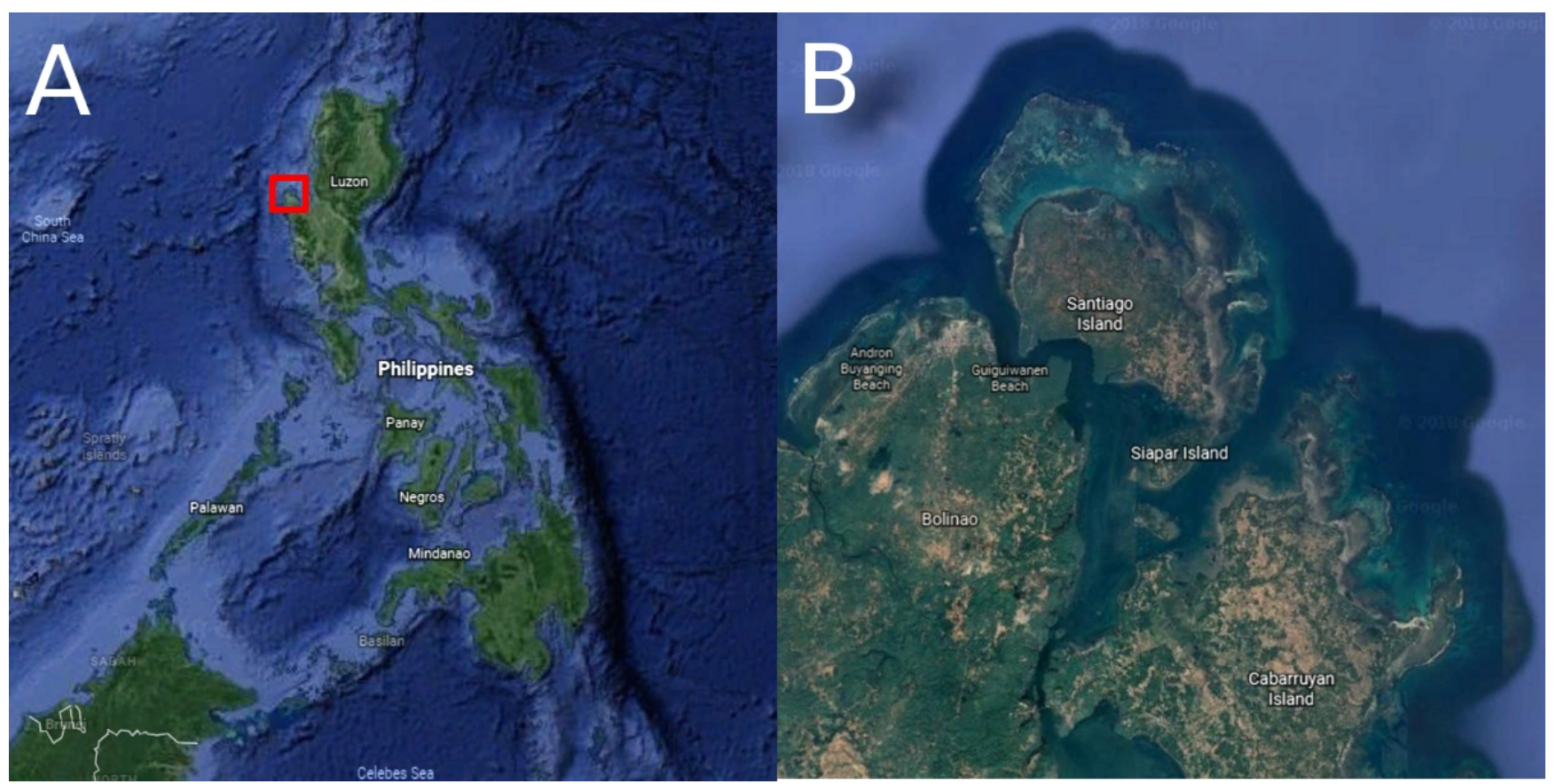

146 Fig. 1. Survey area around Santiago island (B) in the Bolinao region, Pangasinan province,

147 Luzon island, Philippines (A). 
bioRxiv preprint doi: https://doi.org/10.1101/2020 03.20.999722; this version posted March 21, 2020. The copyright holder for this preprint (which was not certified by peer review) is the author/funder, who has granted bioRxiv a license to display the preprint in perpetuity. It is made available under aCC-BY-NC-ND 4.0 International license.

151 Fig. 2. Photographs of several species encountered in the Bolinao area (top to bottom, left to 152 right): Mahidolia mystacina, Amblyeleotris fortanesii, Myersina lachneri, Amblygobius

\section{3 buanensis.}
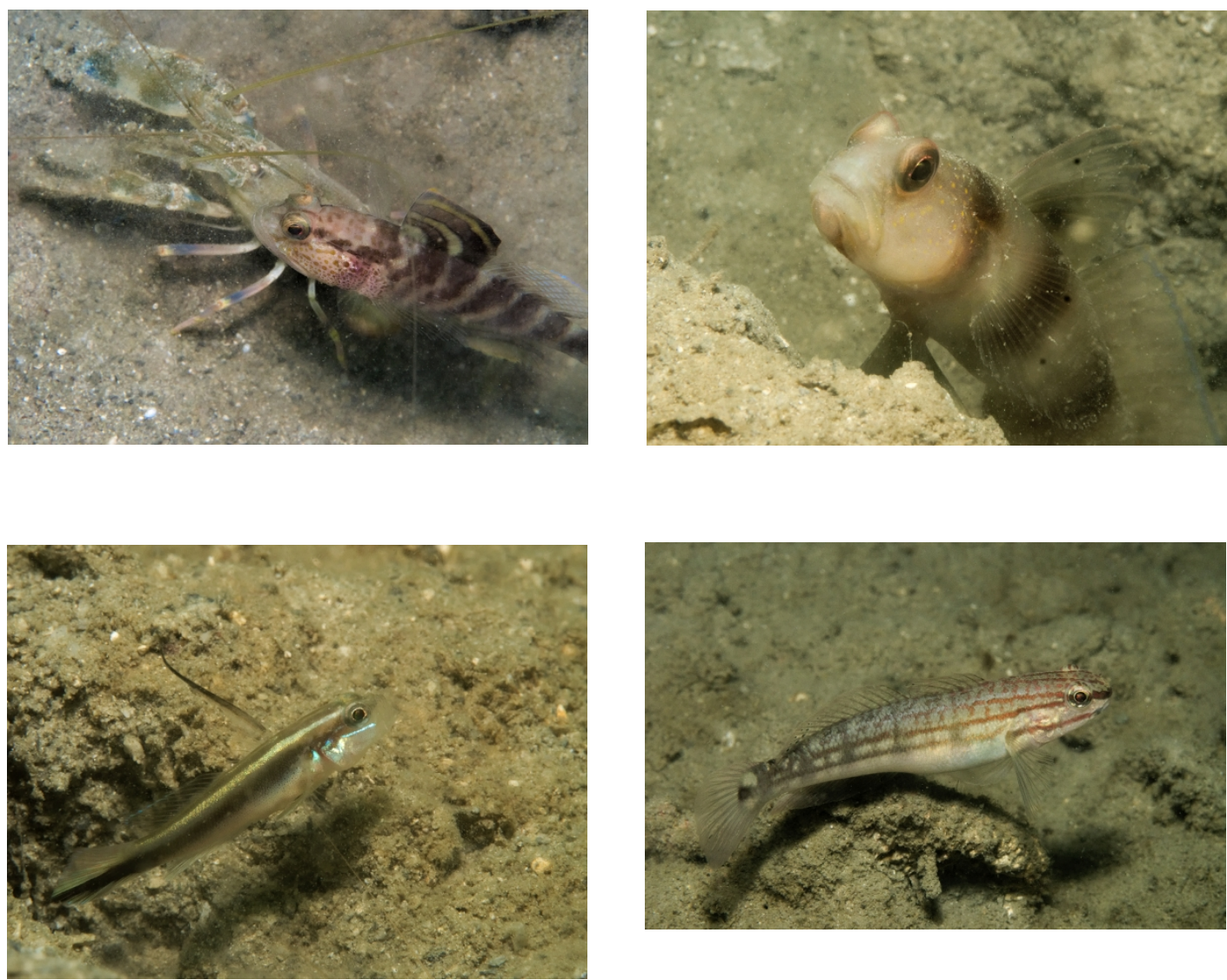


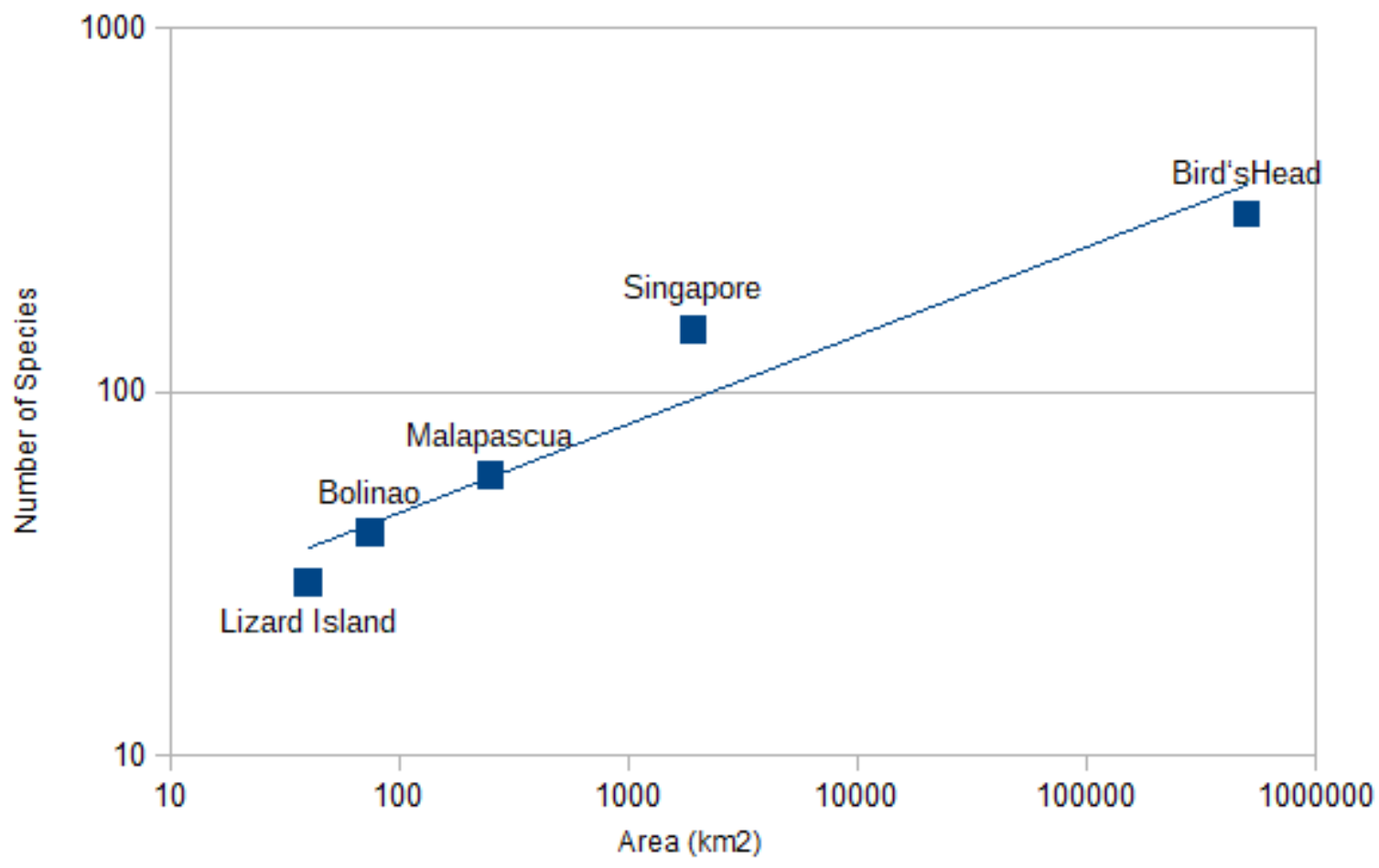

156 Fig. 3. Species - area relationship for marine gobies. Plotted are the number of species against

157 the estimated survey area from this study $\left(\sim 75 \mathrm{~km}^{2}, 40\right.$ species $)$, a study of the gobies of Lizard

158 Island ( $40 \mathrm{~km}^{2}, 30$ species $)$, of Malapascua, Cebu province, Philippines $\left(\sim 250 \mathrm{~km}^{2}, 59\right.$

159 species $)$, of Singapore ( $1925 \mathrm{~km}^{2}, 149$ species) and the Papuan Bird's Head Peninsula ( $\sim 50000$

$160 \mathrm{~km}^{2}, 308$ species).

161 